\title{
Identifikasi Parasetamol dalam Jamu Pegal Linu Menggunakan Metode Kromatografi Lapis Tipis (KLT)
}

\author{
Iqbal Kamar*1 ${ }^{*}$ Fazrina Zahara ${ }^{1}$, Dewi Yuniharni ${ }^{1}$, Rizkya Umi Umairah ${ }^{1}$ \\ ${ }^{1}$ Program Studi Farmasi Universitas Sains Cut Nyak Dhien \\ J. Jendral Ahmad Yani No.8 Gampong Jawa, Langsa Aceh 24416, Indonesia \\ *Corresponding author: iqbalkamar11@gmail.com
}

\begin{abstract}
ABSTRAK
Tujuan penelitian ini adalah untuk mengetahui ada tidaknya kandungan Bahan Kimia Obat (BKO) parasetamol dalam sediaan jamu pegal linu yang beredar di pasar Kota Langsa. Metode penelitian dilakukan secara deskriptif dan Eksperimental di Laboratorium Kimia dan Farmakognosi Universitas Sains Cut Nyak Dhien Langsa dengan menggunakan Metode Kromatografi Lapis Tipis (KLT). Sebanyak 5 sampel jamu yang diambil dengan Teknik Random Sampling. Hasil penelitian yang diperoleh berdasarkan hasil Nilai RF dari KLT diketahui bahwa sampel jamu pegal linu SB negatif mengandung Parasetamol dengan hasil Nilai Rf $0,27,0,33$, dan 0,22 ditiga kali pengulangan, sedangkan sampel jamu pegal linu SA, SC, SD, dan SE positif mengandung Parasetamol dengan hasil Nilai $\mathrm{RF}=1$ di tiga kali pengulangannya. Sehingga dapat disimpulkan bahwa 4 sampel jamu Positif mengandung BKO Parasetamol, sedangkan 1 sampel jamu Negatif mengandung BKO Parasetamol.
\end{abstract}

Kata Kunci: Jamu, Bahan Kimia Obat, Parasetamol

\section{PENDAHULUAN}

Jamu merupakan obat tradisional asli Indonesia yang berasal dari bahan tanaman maupun dari hewan disajikan secara tradisional dalam bentuk seduhan, serbuk, cair, pil atau kapsul [1]. Pemanfaatan jamu berdasarkan data riset kesehatan dasar menunjukan peningkatan sebanyak dari 35,7\% ditahun 2007 menjadi $59,12 \%$ di tahun 2010 [2]. Alasan meningkatnya penggunaan jamu akibat dari turunnya daya beli masyarakat terhadap obat kimia sintetik dan juga masyarakat menganggap jamu relatif lebih aman dibandingkan obat sintesis [3].

Meningkatnya permintaan pasar akan jamu membuat adanya produsen tidak bertanggung jawab yang menambahkan Bahan Kimia Obat (BKO) pada produknya untuk meningkatkan penjualan. Pada tahun 2014 BPOM RI mengeluarkan public warning No. HM.03.05.1.43.11.13.4940 yang mencantumkan 59 jenis jamu [4]. Sedangkan tahun 2015 BPOM menemukan 25 merek atau jenis obat tradisional ber $\mathrm{BKO}$, yang ke 25 obat tersebut mengandung BKO sildenafil dan turunannya [5]. Padahal dalam peraturan Menteri Kesehatan Republik Indonesia No: 246/Menkes/Per/V/1990 Tentang Izin Usaha Industri Obat Tradisional Dan Pendaftaran Obat Tradisional, bahwa obat tradisional tidak boleh mengandung bahan kimia sintetik atau hasil isolasi yang berkhasiat sebagai obat dan tidak mengandung bahan yang tergolong obat keras atau narkotika.

BKO merupakan senyawa kimia sintetis atau berasal dari produk isolat senyawa kimia bahan alam yang umumnya digunakan pada pengobatan modern [6]. Adanya BKO dalam produk jamu dapat membahayakan konsumen, seperti kontra indikasi jamu terhadap penyakit tertentu yang diderita pasien. Masalah lain yang cukup serius dari mengkonsumsi jamu mengandung BKO yaitu terjadinya perforasi lambung dan gagal ginjal sebagai efek samping dari penambahan BKO tersebut [2]. Beberapa jenis produk herbal yang sering dicampurkan dengan BKO antara lain adalah produk pelangsing tubuh, stamina pria, untuk gangguan asam urat atau encok, pegal linu, flu, tulang dan kegemukan badan. Bahan-bahan kimia berbahaya yang sering digunakan meliputi Metampiron, Fenilbutazon, Deksametason, Allopurinol, CTM, Sildenafil sitrat, Tadalafil dan Parasetamol. Obat yang mengandung bahan kimia tersebut memiliki efek samping berbahaya. Misalnya jamu yang mengandung Fenilbutazon dapat menyebabkan peradangan lambung 
dalam jangka panjang akan merusak hati dan ginjal [7].

Hasil penelitian Isnan Ary Surahman (2017), menunjukan kelima sampel jamu memberikan 2 nilai $\mathrm{Rf}$ atau noda, $\mathrm{Rf}$ pertama mendekati $\mathrm{Rf}$ parasetamol dan $\mathrm{Rf}$ kedua identik dengan baku fenilbutazon. Ditinjau dari pola spektra, $\lambda$ maks, dan match factor, noda pertama tidak sama dengan baku parasetamol dan noda kedua sampel positif mengandung BKO fenilbutazon. Menyebutkan dengan rata-rata kadar fenilbutazon sebesar sampel $A=83,87 \% \mathrm{~b} / \mathrm{v}$, sampel $B=222,44 \% b / v$, sampel $C=125,67 \%$ $\mathrm{b} / \mathrm{v}$, sampel $\mathrm{D}=84,47 \% \mathrm{~b} / \mathrm{v}$, dan sampel $\mathrm{E}=$ $66,37 \%$ b/v. Ditemukannya fenilbutazon dalam jamu pegal linu dapat membahayakan pasien karena tidak diketahui lama penggunaan dan takaran minum jamu [8]. Dengan temuan tersebut disarankan untuk pemerintah memberikan peringatan bagi produsen dan penyuluhan tentang bahaya jamu yang mengandung BKO kepada masyarakat. Masyarakat dihimbau agar berhati-hati dalam membeli jamu atau dapat membuat jamu sendiri dirumah dengan bahan yang mudah didapat.

Hayun dan Karina (2016) melakukan penelitian BKO dalam sediaan jamu, jenis BKO yang diperiksa adalah Parasetamol. Efek samping parasetamol adalah kerusakan darah, kerusakan hati dan ginjal. Untuk menjamin keamanan dan khasiat obat tradisional yang beredar pemerintah perlu melakukan pengawasan mutu dan uji kualitas terhadap jamu yang beredar. Untuk melakukan pengawasan tersebut dapat dilakukan analisis kimia terhadap sediaan jamu di pasaran. Saat ini metode analisis kimia sudah banyak dikembangkan antara lain Kromatografi Cair Kinerja Tinggi (KCKT), Kromatografi CairSpektrometri Massa (MS), Kromatografi-Nuclear Magnetic Resonance (NMR), dan Kromatografi Lapis Tipis (KLT)-Densitometri [9].

Harmita (2015) melakukan penelitian dengan metode KLT yaitu dengan cara membuat baku pembanding, mengekstraksi sampel dan menotolkan pada plat KLT kemudian dieluasi dengan fase gerak kloroform:etanol (8:1). Setelah itu dianalisis secara kualitatif dengan cara melihat nilai retention factor (Rf). Setelah analisis kualitatif BKO yang diteliti ditemukan pada sampel, selanjutnya dihitung besarnya kadar BKO dalam sampel [10]. Tujuan dari penelitian ini adalah untuk mengetahui adanya kandungan Parasetamol dalam sediaan jamu pegal linu yang dijual di beberapa toko di Kota Langsa.

\section{BAHAN DAN METODE}

\section{Bahan}

Bahan yang digunakan yaitu :Sampel 1:SA, Sampel 2:SB, Sampel 3:SC, Sampel 4:SD, Sampel 5:SE, Parasetamol, silika gel GF254, etanol $96 \%$, kloroform, kloralhidrat, kertas saring.

\section{Metode}

Pembuatan Pembanding Parasetamol.

Gerus parasetamol didalam lumpang hingga homogen, ditimbang sebanyak $50 \mathrm{mg}$ lalu ditambahkan pelarut etanol $96 \%$ sebanyak $10 \mathrm{ml}$, kocok hingga homogen kemudian disaring dengan menggunakan kertas saring dan di masukkan dalam vial.

\section{Pembuatan Larutan Uji}

Sampel jamu ditimbang $\pm 500 \mathrm{mg}$ kemudian ditambah dengan $10 \mathrm{ml}$ etanol $96 \%$, disaring kemudian diuapkan.

\section{Pembuatan Fase Gerak}

Diukur $9 \mathrm{ml}$ etil asetat dan $1 \mathrm{ml}$ kloroform untuk membuat fase gerak dengan perbandingan 9:1, lalu masukkan etil asetat dan kloroform kedalam chamber tunggu hingga jenuh.

\section{Uji KLT}

Totolkan larutan sampel uji dan larutan sampel parasetamol padaplat KLT yang sama, masukkan plat KLT pada bejana/chamber kromatografi yang telah berisi larutan pengembang (eluen), amati titik noda pada plat $\mathrm{KLT}$, hitung nilai $\mathrm{Rf}$ dan bandingkan nilai $\mathrm{Rf}$ dengan nilai Rf baku standar Bahan Kimia Obat (BKO). 
Uji Organoleptik

Ditimbang masing-masing sampel $\pm 50 \mathrm{mg}$, kemudian diamati warna, bentuk, bau, dan rasanya.

\section{Uji Mikroskopik}

Ditimbang masing-masing sampel $\pm 50 \mathrm{mg}$, diambil sampel kemudian diletakkan diatas objek glass, diberi pelarut chloral hydrate, lalu ditutup dengan dekglass, dan diamati dengan menggunakan mikroskop.

\section{Analisis Data}

Bila nilai Rf larutan Uji dan larutan baku parasetamol sama, berarti sampel tersebut mengandung bahan kimia obat (BKO) yaitu parasetamol. Perhitungan nilai Rf didasarkan atas rumus:

$R f=\frac{\text { Jarak yang ditempuh oleh } \text { komponen }}{\text { Jarak yang ditempuh oleh pelarut }}$

Nilai Rf dinyatakan hingga angka 1,0, Nilai Rf yang baik menunjukkan pemisahan yang cukup baik adalah berkisar antara 0,2-0,8.

\section{HASIL DAN PEMBAHASAN}

Definisi obat tradisional menurut UndangUndang No.23 tahun 1992 adalah bahan atau ramuan atau bahan berupa bahan tumbuhan, bahan hewan, bahan mineral, sediaan sarian (galenik) atau campuran dari bahan-bahan tersebut yang secara turun-temurun telah digunakan untuk pengobatan berdasarkan pengalaman. Berdasarkan Keputusan Kepala Badan POM RI No.Hk.00.05.4.2411 tentang ketentuan pokok dan pengelompokkan dan penandaan obat bahan alam Indonesia, obat tradisional dikelompokkan menjadi tiga, yaitu jamu, obat herbal terstandar, dan fitofarmaka. Obat tradisional di larang mengandung: Etil Alkohol dari 1\% kecuali dalam bentuk sediaan tingtur yang pemakaiannya dengan pengenceran.

Fakta menyatakan bahwa memang ada beberapa bahan ramuanobat tradisional yang baru diketahui bahayanya setelah melewati berbagai macampenelitian.Beberapa bahanbahan ada yang bersifat keras dan jarang digunakan,selain untuk beberapa penyakit tertentu dan digunakan dengan cara-cara tertentu pula. Bahan berbahaya yang dimaksud adalah suatu bahan (baik alami maupunsintesis, organik maupun anorganik) yang karena dalam keadaan, jumlah, dosis danbentuk tertentu dapat mempengaruhi fungsi organ tubuh manusia atau hewansedemikian sehingga dapat mengganggu kesehatan baik sementara, tetap atausampai menyebabkan kematian [11]. Pernyataan tersebut dapat berkaitan dengan bahayanya pemberian bahan kimia obat pada sediaan obat tradisional, yangmana toksisitas dan interaksi ramuan obat tradisional terhadap bahan kimia obat belum diketahui.

Bahan kimia obat adalah bahan kimia hasil isolasi atau sintetik yang berkhasiat obat. Uji keberadaan bahan kimia obat dalam jamu pegal linu yang telah diseduh dari toko maupun yang belum diseduh dilakukan dengan menggunakan metode kromatografi lapis tipis. Kromatografi lapis tipis ialah metode pemisahan fisikokimia. Lapisan yang memisahkan, yang terdiri atas bahan berbutir-butir (fase diam), ditempatkan pada penyangga berupa plat gelas, logam, atau lapisan yang cocok.

\section{Uji Organoleptik}

Uji organoleptik dilakukan dengan cara melihat bentu,warna, warna, bau, rasa, alamat produk, homogenitas, Kadaluarsa, nomor Registrasi dan kemasan pada setiap sampel jamu Pegel Linu. Hasil pengamatan secara Organoleptik dapat dilihat pada Tabel 1. Dari hasil pengamatan secara organoleptik di dapat hasil hanya pada sampel SE yang terdapat logo halal sedangkan sampel yang lain tidak terdapat logo halal.

\section{Uji Mikroskopik}

Uji mikroskopik dilakukan dengan cara melihat sampel jamu dengan menggunakan mikroskop untuk melihat fragmen penganal pada setiap sampel Jamu Pegel Linu. Sampel SA pada preparat berwarna kuning, amilum besar bulat panjang dan terdapat granul pati dalam air dan serat sklerenkim berombak. Sampel SA menunjukan bentuk dari tananaman herbal dari Curcuma Rhizoma dan Zingeberis Rhizoma. Sampel SB dan SD menujukan hasil pengamatan pada preparat berwarna kuning, amilum besar bulat panjang, terdapat granul pati dalam air, serat sklerenkim berombak, amilum 
besar seperti biji ketimun (dalam air), dan gumpalan sekresi coklat. Pada sampel SB dan SD bentuk mikrokopik terdapat pada tanaman herbal seperti Curcuma Rhizoma, Zingeberis Rhizoma, Galangae Rhizoma dan Kaempferae
Rhizoma. Sampel SC dan SE menujukan hasil pengamatan pada preparat terdapat granul pati dalam air dan serat sklerenkim berombak, ini tanaman herbal Zingeberis Rhizoma.
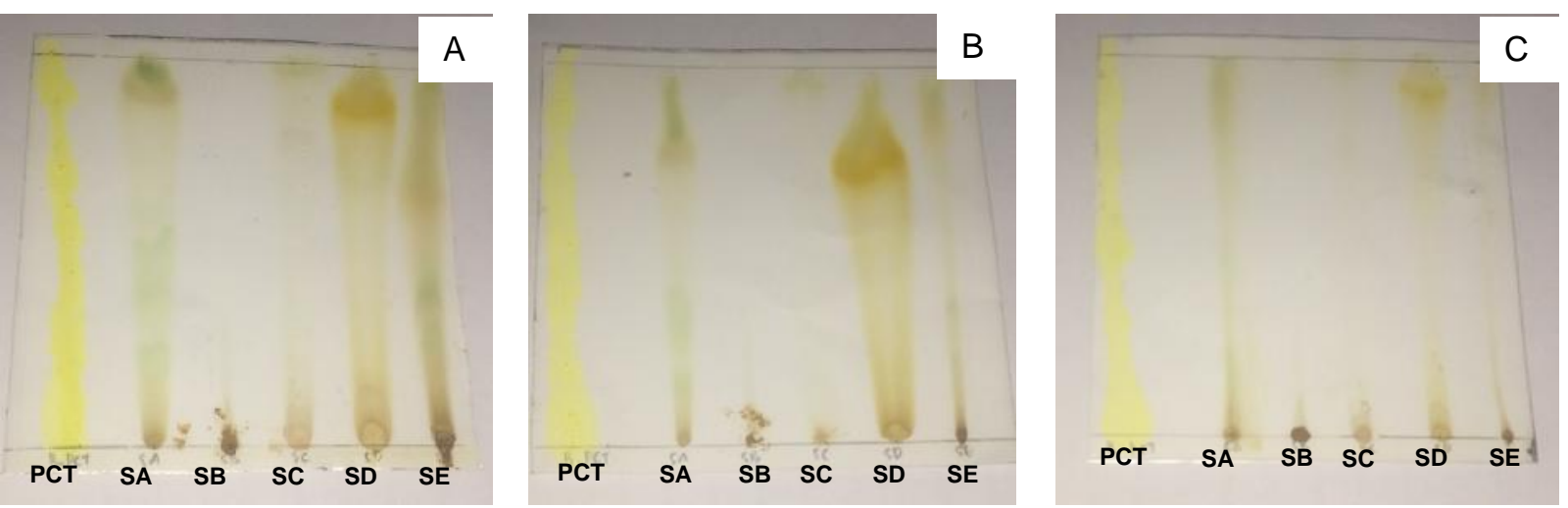

Gambar 1. Hasil penelitian parasetamol pada jamu pegal linu (a) Pengulangan pertama (b)

Pengulangan kedua (c) Pengulangan ketiga

Tabel 1. Hasil pengamatan organoleptik

\begin{tabular}{|c|c|c|c|c|c|}
\hline \multirow[t]{2}{*}{ Pengamatan } & \multicolumn{5}{|c|}{ Sampel } \\
\hline & SA & SB & $\mathrm{SC}$ & SD & SE \\
\hline Bentuk & Serbuk & Serbuk & Serbuk & Serbuk & Serbuk \\
\hline Warna & Hijau muda & $\begin{array}{c}\text { Kuning } \\
\text { kehijauan }\end{array}$ & $\begin{array}{l}\text { Coklat } \\
\text { muda }\end{array}$ & $\begin{array}{l}\text { Kuning } \\
\text { cerah }\end{array}$ & Kuning pucat \\
\hline Bau & Aromatik & Aromatik & Aromatik & Aromatik & Aromatik \\
\hline Rasa & Pahit & Pahit & $\begin{array}{c}\text { Tidak } \\
\text { berasa }\end{array}$ & Pahit & Pedas \\
\hline Alamat produk & Semarang & Semarang & Surakarta & Solo & Tangerang \\
\hline Homogenitas & $\begin{array}{l}\text { Tercampur } \\
\text { rata }\end{array}$ & $\begin{array}{l}\text { Tercampur } \\
\text { rata }\end{array}$ & $\begin{array}{l}\text { Tercampur } \\
\text { rata }\end{array}$ & $\begin{array}{l}\text { Tercampur } \\
\text { rata }\end{array}$ & Tercampur rata \\
\hline Exp. Date & Juli 2021 & $\begin{array}{c}\text { Oktober } \\
2020\end{array}$ & $\begin{array}{c}\text { September } \\
2021\end{array}$ & $\begin{array}{c}\text { Agustus } \\
2021\end{array}$ & Januari 2023 \\
\hline No. Reg & $\begin{array}{l}\text { POM TR. } \\
082280541\end{array}$ & $\begin{array}{c}\text { POM TR. } \\
102219821\end{array}$ & $\begin{array}{c}\text { POM TR. } \\
013211661\end{array}$ & $\begin{array}{l}\text { POM TR. } \\
092206191\end{array}$ & $\begin{array}{c}\text { POM TR. } \\
152384211\end{array}$ \\
\hline Kemasan & Sachet & Sachet & Sachet & Sachet & Kapsul \\
\hline Logo Halal & - & - & - & ada & - \\
\hline
\end{tabular}

\section{Kromatografi Lapis Tipis (KLT)}

Parasetamol merupakan obat analgetik non narkotik dengan cara kerja menghambat sintesis prostaglandin terutama pada sistem saraf pusat. Efek adaya parasetamol yang berlebih pada jamu tradisional dapat menyebabkan gangguan sistem pencernaan berupa mual, muntah, pucat, 
berkeringat dan lebih parah dapat menyebabkan kerusakan hati. Untuk mengetahui adanya kandungan parasetamol dalam jamu dapat dilakukan pengujian dengan kualitatif dan kuantitatif. Adapun uji kualitatifnya yaitu dengan menggunakan Metode KLT. Metode KLT digunakan karena KLT merupakan metode yang sederhana dan cepat. KLT digunakan secara luas untuk analisis obat [12]

Metode kromatografi lapis tipis (KLT) dapat memisahkan komponen-komponen berdasarkan perbedaan tingkat interaksi dalam dua fasa material pemisah. KLT dapat digunakan untuk mengidentifikasi senyawa yang terdapat dalam campuran secara kualitatif, yaitu dengan membandingkan $\mathrm{Rf}$ baku pembanding dengan Rf sampel. Selain itu, KLT merupakan teknik analisis yang sederhana, hemat biaya, mudah dilakukan, dan hanya dibutuhkan sedikit cuplikan sampel untuk analisisnya [13] .

Prinsip kerja KLT yaitu adsorpsi, desorpsi, dan elusi. Adsorpsi terjadi ketika larutan sampel ditotolkan ke fase diam (plat KLT) menggunakan pipa kapiler, komponen-komponen dalam sampel akan teradsorbsi di dalam fase diam. Desorbsi adalah peristiwa ketika komponen yang teradsorbsi di fase diam didesak oleh fase gerak (eluen), terjadi persaingan antara eluen dan komponen untuk berikatan dengan fase diam. Elusi adalah peristiwa ketika komponen ikut terbawa oleh eluen.

Pada penelitian ini, Idetifikasi Parasetamol pada sediaan jamu pegal linu dengan menggunakan metode Kromatografi Lapis Tipis (KLT) dengan fase diam Silika Gel GF 254 dan fase gerak Etil Asetat:N-Heksan (9:1). Fase diam silika gel GF 254 yang memiliki sifat relatif polar, mengandung silika dengan gipsum sebagai agen pengikat, dan indikator fluoresen yang dapat berfluorosensi. Silika gel memiliki gugus hidroksil yang dapat membentuk ikatan sehingga dapat menyerap dan mengikat sampel di permukaan. Sedangkan untuk fase gerak pada penelitian ini menggunakan Etil Asetat:N-Heksan (9:1) bersifat nonpolar yang akan menahan senyawa yang polar pada fasa diam yang bersifat polar dan akan membawa senyawa yang kurang polar naik ke atas. Eluen dibuat jenuh dengan cara menutup rapat chamber dan mendiamkannya selama beberapa saat agar atmosfer dalam chamber terjenuhkan dengan uap pelarut sehingga eluasi kecepatan eluen sama pada semua sisi permukaan plat KLT.

Hasil uji KLT pada penelitian ini dapat diligat pada gambar 1 dan tabel 1. Dari pengujian KLT satu kali pengulangan pada sampel jamu pegal linu yang beredar di pasar Kota Langsa hasil yang didapat ialah hanya pada sampel SB yang negatif mengandung parasetamol dengan hasil nilai $\mathrm{Rf} 0,27$ sedangkan keempat sampel yang lain positif mengandung parasetamol dengan hasil nilai Rf sama yaitu 1. Dari pengujian KLT dua kali pengulangan pada sampel jamu pegal linu yang beredar di pasar Kota Langsa hasil yang didapat ialah hanya pada sampel SB yang negatif mengandung parasetamol dengan hasil nilai $\mathrm{Rf}$ 0,33 sedangkan keempat sampel yang lain positif mengandung parasetamol dengan hasil nilai Rf sama yaitu 1.

Gambar 1. Dapat dilihat hasil pengujian KLT dengan tiga kali pengulangan pada sampel jamu pegal linu yang beredar di pasar Kota Langsa hasil yang didapat ialah hanya pada sampel SB yang negatif mengandung parasetamol dengan hasil nilai $\mathrm{Rf}$ rata-rata 0,27 dan tidak terdapat bercak kuning. Sedangkan keempat sampel yang lain positif mengandung parasetamol dengan hasil nilai $\mathrm{Rf} 1$ dan terdapat noda kuning pada hasil pengujian sampel dengan metode KLT.

Tabel 2. Nilai hasil rata-rata RF pada sampel jamu pegal linu dengan tiga kali pengulangan

\begin{tabular}{ccccccc}
\hline \multirow{2}{*}{ Sampel } & \multicolumn{3}{c}{ Pengulangan } & $\begin{array}{l}\text { Rata- } \\
\text { rata }\end{array}$ & Hasil \\
\cline { 2 - 5 } & Satu & Dua & Tiga & RF & \\
\hline SA & 1 & 1 & 1 & 1 & Positif \\
SB & 0,27 & 0,33 & 0,22 & 0,27 & Negatif \\
SC & 1 & 1 & 1 & 1 & Positif \\
SD & 1 & 1 & 1 & 1 & Positif \\
SE & 1 & 1 & 1 & 1 & Positif \\
\hline
\end{tabular}

Dari hasil ketiga pengulangan KLT pada sampel jamu pegal linu di dapat hasil nilai rata-rata pada sampel SA, SC, SD, dan SE sama yaitu 1 yang menunjukkan pada keempat sampel tersebut positif mengandung parasetamol sedangkan hasil nilai rata-rata pada SB yang berbeda yaitu 0,27 yang menunjukkan pada sampel SB Negatif mengandung parasetamol. 


\section{KESIMPULAN}

Dari kelima sampel yang diteliti dengan tiga kali pengulangan/perlakuan diantaranya positif mengandung Parasetamol yaitu sampel SA, SC, SD, dan SE. Sampel yang positif mengandung Parasetamol tidak memiliki selisih hasil Rf di tiga kali pengulangan/perlakuannya. Untuk hasil yang negatif mengandung Parasetamol yaitu pada sampel SB dengan selisih nilai hasil RF $<10 \%$ di tiga kali pengulangan. Dan hasil pengamatan Organoleptis pada kemasan dan isi jamu hanya satu sediaan jamu yang mempunyai logo halal yaitu sampel SE.

\section{REFERENSI}

[1] Jayanti, R., Aprilia, H., Lukmayani. Y., Analisis Bahan Kimia Obat (BKO) Glibenklamid Dalam Sediaan Jamu Diabetes Yang Beredar Dipasaran. Prosiding Penelitian SPeSIA 2015. Surabaya: Prodi Farmasi FMIPA Unisba, 2015. p. 649-653.

[2] Purwaningsih, E.H., Jamu, Obat Tradisional Asli Indonesia Pasang Surut Pemanfaatannya di Indonesia. Jakarta. eJKI. Departemen Farmasi Fakultas Kedokteran Universitas Indo. 2017

[3] Susila, P.O., Identifikasi dan Kuantifikasi Bahan Kimia Obat Sibutramin Dalam Jamu Pelangsing Yang Beredar Di Sekitar Surakarta Menggunakan Metode Spektrofotometri UV-VY.Surakarta: Skripsi. Fakultas Farmasi, Universitas Muhammadiyah Surakarta. 2017. p. 15-16.

[4] BPOM, Peraturan Badan Pengawas Obat dan Makanan Republik Indonesia Nomor 12 Tahun 2014 Tentang Persyaratan Mutu Obat Tradisional. Sekretariat Negara. Jakarta.Hal 7.

[5] BPOM,Bahaya Jamu Yang Mengandung Bahan Kimia Obat.http://IK.pom.go.id/v201 2/q-a/bahaya-jamu-yang-mengandung-bko. 2015. Diakses Tanggal 26 Maret 2020.

[6] Anggraeni, D.L., Rusdi, B dan Hilda, A.W., Pengembangan Metode Analisis Parasetamol dan Deksametason Pada Jamu Pegal Linu Menggunakan Metode Ekskresi Fasa Pada dan Kromatografi Cair Kinerja Tinggi. Prosiding Penelitian SPeSIA Unisba. 2015.
[7] Latif A,. Analisis Alupurinol Pada Sediaan Jamu Serbuk Asam Urat Yang Beredar di Purwokerto. Fakultas Farmasi- Universitas Muhammadiyah Purwokerta. 2018. p. 1145.

[8] Isnan Ary Surahman, Analisis Bahan Kimia Obat Dalam Sediaan Jamu Cair Pegal Linu Tanpa Merek Dengan Metode KItdensitometri, Skripsi Sarjana, Universitas Muhammadiyah Malang, 2017, p. 57

[9] Hayun, Karina, M.A, Pengembangan dan Validasi Metode KLT. Desintrometri untuk Analisis Secara Simultan Parasetamol, Asam Mefenamat dan Ibu Profen dalam Jamu "Pegal Linu". Jurnal Sains farmasi\&Klinis. Sumatra Barat: Ikatan Apoteker Indonesia. 2016. 2 (2) p.150-161

[10] Harmita, Analisis Fisikokimia Kromatografi Volume 2. EGC. Jakarta. 2015. 9 (1).p.22.

[11] Katno, Tingkat Manfaat, Keamanan dan Efektifitas Tanaman Obat dan Obat Tradisional. Karanganhya: B2P2TP-OT. 2018.

[12] A. Wirastuti, A. A. Dahlia, and A. Najib, "Pemeriksaan Kandungan Bahan Kimia Obat (BKO) Prednison Pada Beberapa Sediaan Jamu Rematik," Fitofarmaka Indones., vol. 3, no. 1, pp. 130-134, 2017.

[13] F. Husna and S. R. Mita, "Identifikasi Bahan Kimia Obat Dalam Obat Tradisional Stamina Pria Dengan Metode Kromatografi Lapis Tipis," Farmaka, vol. 18, no. 2, pp. 16-25, 2018. 